Marek Jaśkowski

\title{
Analiza opracowania pt. „Polowania na ptaki. Zgodność z prawem międzynarodowym, unijnym i krajowym. Aspekt ochrony przyrody i humanitarno-prawny"1
}

\author{
Analysis of the study "Bird hunting. Compliance with international, EU \\ and national law. Aspect of nature protection as well as a humanitarian \\ and legal aspect"
}

According to the author, in numerous aspects the assessment of the compliance with the Birds Directive can be carried out at the local level, taking into account elements such as habitat characteristics, the nature of the hunt or the degree of actual probability of the error due to the similarity of hunted and protected species. The thesis that pheasants and partridges can be considered as game only after the maturity of their own broods is too far-reaching. According to the author, the use of lead shot in areas of special protection may be considered incompatible with the protection requirements of these areas, and the practice of general exclusion of hunting plans from the requirement to undergo an impact assessment on a given area may be considered incompatible with the Habitats Directive.

Keywords: hunting, wildlife conservation, animal protection, Hunting Law, European Union

W ocenie autora, na wielu płaszczyznach ocena zgodności z dyrektywą ptasią może być przeprowadzana na poziomie lokalnym, z uwzględnieniem takich elementów jak cechy siedliska, charakter polowania czy rzeczywiste prawdopodobieństwo wystąpienia pomyłki wskutek podobieństwa gatunków łownych i chronionych. Teza, zgodnie z którą bażanty i kuropatwy mogą zostać uznane za zwierzynę łowną dopiero po okresie wyprowadzenia własnych lęgów, jest zbyt daleko idąca. Zdaniem autora, stosowanie śrutu ołowianego na obszarach szczególnej ochrony może zostać uznane za niezgodne z wymogami ochrony tych terenów, zaś praktyka polegająca na generalnym wyłączeniu planów łowieckich spod wymogu poddania ocenie wpływu na dany teren może zostać uznana za niezgodną z dyrektywą siedliskową.

Słowa kluczowe: łowiectwo, ochrona przyrody, ochrona zwierząt, prawo łowieckie, Unia Europejska

Doktor nauk prawnych, adiunkt Uniwersytet Kardynała Stefana Wyszyńskiego w Warszawie, Wydział Prawa i Administracji, Katedra Prawa Międzynarodowego i Europejskiego, WARSZAWA, POLSKA • marek.jaskowski@sejm.gov.pl • https://orcid.org/0000-0001-6598-810X

1 Opinia dotycząca opinii „Polowania na ptaki. Zgodność z prawem międzynarodowym, unijnym i krajowym. Aspekt ochrony przyrody i humanitarno-prawny" sporządzona 23 stycznia 2020 r. na zlecenie posła Klubu Parlamentarnego Platforma Obywatelska Koalicja Obywatelska; BAS-WAPM 162/19. 


\section{Przedmiot opinii}

Niniejsza opinia stanowi analizę zasadniczych tez zawartych w opinii „Polowania na ptaki. Zgodność z prawem międzynarodowym, unijnym i krajowym. Aspekt ochrony przyrody i humanitarno-prawny" dr Magdaleny Micińskiej (dalej: analizowania opinia).

Niniejsza opinia dotyczy aspektów prawnych powyższego zagadnienia, w szczególności oceny zgodności wskazanych przepisów i praktyk z normami prawa UE i prawa międzynarodowego. Poza zakresem opinii pozostają zwłaszcza uwagi, w których Autorka analizowanej opinii dokonuje oceny raczej o charakterze moralnym niż prawnym [(np. chociaż w ocenie Autorki na tle humanitarno-prawnego standardu uśmiercania kręgowców polowania na ptaki stanowia rażacy, demoralizujacy anachronizm prawniczy (s. 23 analizowanej opinii), to jednak przyznaje ona, że: prawo międzynarodowe, unijne i krajowe nie wprowadziło szczegółowych wymogów humanitarnych odnośnie polowań (s. 21 analizowanej opinii)].

Z uwagi na odwoływanie się przez Autorkę w znacznym stopniu do prawa UE i do konwencji berneńskiej², wstępna część opinii została poświęcona relacjom między tą konwencją a prawem UE, zwłaszcza dyrektywami 2009/147/WE oraz 92/43/EWG. Kolejne części niniejszej opinii stanowią odniesienie do poszczególnych tez zawartych w analizowanej opinii.

\section{Relacje między konwencją berneńską a dyrektywami 2009/147/WE oraz 92/43/EWG}

W analizowanej opinii zawarte zostały zarzuty niezgodności określonych regulacji polskich z konwencją berneńską i dyrektywami 2009/147/WE oraz 92/43/ EWG. Jednocześnie należy zauważyć daleko posunięte podobieństwo między niektórymi przepisami, z jednej strony konwencji berneńskiej, a z drugiej - obu wspomnianych dyrektyw. W związku z tym punktem wyjścia dla niniejszej opinii należy uczynić wyjaśnienie relacji między tymi aktami prawnymi, w szczególności w celu ustalenia zależności interpretacyjnych między nimi.

Konwencja o ochronie gatunków dzikiej flory i fauny europejskiej i ich siedlisk została zawarta 19 września 1979 r. i weszła w życie 1 czerwca 1982 r. po osiągnięciu wymaganego progu ratyfikacji (5). Zgodnie z art. 19 ust. 1 konwencji jej stroną mogły stać się nie tylko państwa, ale również Europejska Wspólnota Gospodarcza (obecnie: Unia Europejska). Ówczesna EWG przystąpiła do konwencji na mocy decyzji Rady z 3 grudnia 1981 r. dotyczącej zawarcia konwencji o ochronie gatunków dzikiej flory i fauny europejskiej oraz ich siedlisk

2 Konwencja o ochronie gatunków dzikiej flory i fauny europejskiej i ich siedlisk z 19 września 1979 r. 
(82/72/EWG, Dz.Urz. L 038 z 10 lutego1982 r., s. 1). Konwencja weszła w życie w stosunku do obszarów objętych stosowaniem prawa ówczesnej Europejskiej Wspólnoty Gospodarczej 1 września 1982 r. (Dz.Urz. L 150 z 8 czerwca 1983 r., s. 36). Niezależnie od tego należy zauważyć, że stronami konwencji są jednocześnie wszystkie państwa członkowskie UE.

Jeżeli chodzi o relacje między konwencją berneńską a dyrektywami 2009/147/WE oraz 92/43/EWG, to należy zauważyć, że żadna z tych dyrektyw nie odwołuje się do konwencji. Projekt dyrektywy 79/409/EWG przedłożono w roku 1976 (COM (76) 676), zaś sama dyrektywa została przyjęta 2 kwietnia 1979 r. Trudno więc oczekiwać, aby dokumenty te wprost odwoływały się do konwencji przyjętej we wrześniu 1979 r., która, co więcej, weszła w życie wobec EWG 1 września 1982 r., (jakkolwiek możemy zakładać, że autorzy dyrektywy brali pod uwagę prace nad późniejszą konwencją berneńską ${ }^{3}$, które rozpoczęły się również w 1976 r. ${ }^{4}$. Trzeba jednak zauważyć, że mimo licznych nowelizacji dyrektywy 79/409/EWG, aż do jej uchylenia z mocą od 2010 r., nie zostało w niej zawarte odwołanie do konwencji berneńskiej. Również zastępująca ją dyrektywa 2009/147/WE (ani uzasadnienie towarzyszące jej projektowi) nie wskazuje w swojej treści, aby stanowiła ona akt wdrażający konwencję berneńską na poziomie UE. Podobnie konwencja berneńska jest wielkim nieobecnym w tekście dyrektywy 92/43/EWG.

Mimo to $\mathrm{w}$ praktyce unijnych organów wskazuje się na zależności między tymi dokumentami, aczkolwiek są one ujmowane w różny sposób. Przykładowo, w sprawozdaniu przedstawionym przez Komisję Europejską, zgodnie z wymogami art. 9 ust. 2 konwencji berneńskiej, stwierdza się, że dyrektywa 79/409/EWG (obecnie dyrektywa 2009/147/WE) wraz z dyrektywą 92/43/EWG stanowią unijne ramy wykonywania postanowień tej konwencji ${ }^{5}$. Z taką oceną zgadza się rzecznik generalna J. Kokott, według której: dyrektywa siedliskowa służy - łącznie z dyrektywa ptasia - implementacji konwencji berneńskiej ${ }^{6}$. Na marginesie warto zauważyć,

3 Opinia rzecznika generalnego w sprawie C-57/89, pkt 10.

4 J.P. Ribaut, How the Bern Convention Came into Being, „Naturopa” 2004, No (101), s. 4. 5 SEC/2001/0515 final.

6 Pkt 34 opinii rzecznika generalnego w sprawie C-221/04; pkt 10 opinii rzecznika generalnego w sprawie C-383/09, tak samo w odniesieniu do dyrektywy siedliskowej, acz z lekkim wahaniem, V. Koester, The Bern Convention and I, „Naturopa” 2004, No (101), s. 5; zob. również rezolucję Rady Wspólnot Europejskich i przedstawicieli rządów państw członkowskich zebranych w Radzie z 19 października 1987 r. w sprawie kontynuacji i implementacji polityki dotyczącej środowiska naturalnego i programu działania Wspólnot Europejskich w zakresie ochrony środowiska (1987-1992) (Dz.Urz. UE C 328, s. 1, pkt 5.1.4-5.1.6), gdzie zauważa się potrzebę przyjęcia aktu prawa wspólnotowego zmierzającego do ochrony gatunków fauny i flory, jak również siedlisk gatunków dzikich, m.in. z tego powodu, że wdrażanie konwencji berneńskiej jest wysoce niezadowalające w państwach członkowskich Wspólnoty, i że przyjęcie odpowiedniego instrumentu prawnego na poziomie EWG poprawiłoby tę sytuację. 
że w ramach procedury prowadzącej do przyjęcia dyrektywy siedliskowej Komitet Ekonomiczno-Społeczny wskazał, że celem przedłożonego projektu jest zapewnienie bardziej skutecznej realizacji zobowiązań wynikających z konwencji ${ }^{7}$.

W omawianym kontekście należy też zaznaczyć, że zgodnie z orzecznictwem TSUE akty prawa wtórnego UE należy - w miarę możliwości - interpretować „W świetle prawa międzynarodowego”, w szczególności jeśli są to przepisy, które mają właśnie na celu wprowadzenie w życie umowy międzynarodowej zawartej przez Wspólnotę , lub, jak stwierdził Trybunał przy innej okazji, „,W sposób zgodny” z wiążącymi Unię konwencjami międzynarodowymi ${ }^{9}$. Należy więc zgodzić się z opinią rzecznika generalnego H. Saugmandsgaarda Øe w sprawie C-674/17, zgodnie z którą dokumenty interpretacyjne wydawane na podstawie konwencji berneńskiej mogą stanowić dla TSUE wskazówkę w zakresie interpretacji dyrektywy siedliskowej, jako że dyrektywa ta w znacznym stopniu oparta jest na konwencji berneńskiej $^{10}$. Analogiczny wniosek należy wysnuć w odniesieniu do dyrektywy ptasiej.

Warto też zauważyć, że zgodnie z art. 12 konwencji jej strony mogą zastosować bardziej rygorystyczne środki w celu ochrony dzikiej flory i fauny oraz ich naturalnych siedlisk niż przewidziane w samej konwencji. W tym kontekście oczywisty jest wniosek rzecznika generalnego N. Fennelly’ego, że fakt, iż konwencja nie znajduje zastosowania do niektórych gatunków ptaków (objętych przepisami dyrektywy ptasiej), w żaden sposób nie zwalnia państw członkowskich z obowiązku pełnego wykonania tej dyrektywy, również więc w zakresie wykraczającym ponad standardy ochrony przewidziane w konwencji. Brak zakazu polowań na określone ptaki w konwencji nie może więc być traktowany jako dorozumiane upoważnienie do prowadzenia takich polowań.

\section{Opiniowana teza: „sprowadzanie wysokiego ryzyka zabicia ptaków objętych ochroną gatunkową, płoszenie i niepokojenie ich w siedliskach, koliduje z przepisami art. 6 lit. a, b, i c konwencji berneńskiej, art. 4 ust. 4 i art. 5 lit. a, b, d dyrektywy ptasiej"}

\section{Artykuł 4 ust. 4 dyrektywy 2009/147/WE}

Artykuł 4 ust. 4 dyrektywy 2009/147/WE ${ }^{11}$ (dalej również dyrektywa ptasia) wymaga, aby w odniesieniu do obszarów ochrony gatunków chronionych (określo-

7 Opinion on the proposal for a Council Directive on the protection of natural and seminatural habitats and of wild fauna and flora and on the Supplementary Annexes (91/C 31/01), pkt 1.2.

8 Wyrok TSUE w sprawie C-306/05, pkt 35.

$9 \quad$ Wyrok TSUE w sprawie C-161/08, pkt 38.

10 Opinia rzecznika generalnego w sprawie C-674/17, przypis 57.

11 Dyrektywa Parlamentu Europejskiego i Rady 2009/147/WE z 30 listopada 2009 r. w sprawie ochrony dzikiego ptactwa, Dz.Urz. UE L 20 z 26 stycznia 2010 r., s. 7. 
nych w załączniku I do dyrektywy) i gatunków migrujących państwa członkowskie podjęły właściwe kroki w celu uniknięcia powstawania zanieczyszczenia lub pogorszenia warunków naturalnych siedlisk lub jakichkolwiek zakłóceń wpływających na ptactwo, o ile mają one znaczenie w odniesieniu do celów tego artykułu. Należy przy tym zaznaczyć, że państwa członkowskie są zobowiązane przestrzegać obowiązków, które wynikają z tego przepisu, nawet jeżeli dane obszary nie zostały sklasyfikowane jako obszary specjalnej ochrony, jeżeli okaże się, że powinny były zostać tak sklasyfikowane ${ }^{12}$.

Zgodnie $\mathrm{z}$ analizowaną opinią pobyt myśliwych, psów myśliwskich i pojazdów w siedliskach i kontaminacja środowiska śrutem ołowianym stanowią naruszenie art. 4 ust. 4 dyrektywy ptasiej, ponieważ prowadzą do powstawania zanieczyszczenia lub pogorszenia warunków naturalnych siedlisk lub zakłóceń wpływających na ptactwo. Zagadnienie zanieczyszczenia środowiska śrutem ołowianym zostanie omówione osobno, w dalszej części opinii. Natomiast w odniesieniu do pobytu myśliwych, psów myśliwskich i pojazdów w siedliskach należy zauważyć, że, zgodnie z interpretacją Komisji Europejskiej, art. 4 dyrektywy ptasiej nie sprzeciwia się prowadzeniu polowań jako takich na obszarach szczególnej ochrony, co więcej - na podstawie dyrektyw o ochronie przyrody nie ma ogólnych przesłanek przeciwko polowaniu na terenach sieci Natura 2000. Powinny one jednak być właściwie zarządzane i kontrolowane, aby uniknąć powodowania poważnych zakłóceń na takich obszarach. Polowanie i inne działania człowieka mogą potencjalnie prowadzić do tymczasowego ograniczenia korzystania z siedlisk na danym terenie. Działania takie byłyby znaczące, gdyby prowadziły do wyraźnego zmniejszenia zdolności terenu do utrzymania gatunku, dla którego został on przeznaczony (co jednocześnie prowadziłoby do zmniejszenia możliwości prowadzenia tamże polowań $)^{13}$. Dokonując oceny powagi zakłócenia, należy wziąć pod uwagę takie czynniki, jak charakter i rozmiar terenu, charakter i rozmiar polowania, gatunki występujące na danym obszarze, a także powody, dla których teren jest istotny dla ochrony przyrody, a które doprowadzily do ujęcia go w sieci Natura 2000. W konsekwencji, działania związane z polowaniem na terenach należących do sieci Natura 2000 są zasadniczo kwestiami związanymi z zarządzaniem tymi obszarami, co powinno stanowić przedmiot ustaleń głównie na poziomie lokalnym, za pomocą planu zarządzania (wytyczne 2008, pkt 1.5.7).

Co istotne, $\mathrm{z}$ uwagi na stanowisko zawarte $\mathrm{w}$ analizowanej opinii, $\mathrm{w}$ ocenie Komisji Europejskiej sytuacja polegająca na występowaniu rzadkiego gatunku, który jest bardzo wrażliwy na zakłócenie, obok potencjalnej zwierzyny łownej,

12 Wyrok TSUE w sprawie C-141/14, pkt 67.

13 Wytyczne dotyczące polowania na podstawie dyrektywy Rady 79/409/EWG w sprawie ochrony dzikiego ptactwa, Komisja Europejska 2008 (dalej: wytyczne 2008), pkt 1.5.1, 1.5.3. 
może prowadzić do wniosku, że polowanie byłoby niezgodne z celami ochrony dla poszczególnych terenów. Jednakże Komisja podkreśla konieczność zniuansowanego podejścia, uznając, że przypadki takie mogą być ustalane tylko dla indywidualnych terenów (wytyczne 2008, pkt 1.5.4).

Wobec powyższego należy uznać, że zawarta w analizowanej opinii teza, jakoby pobyt myśliwych, psów myśliwskich i pojazdów w siedliskach stanowiły jako takie naruszenie art. 4 ust. 4 dyrektywy ptasiej jest zbyt daleko idąca. Oceny zgodności z dyrektywą należy bowiem dokonywać na poziomie lokalnym, z uwzględnieniem cech siedliska i charakteru polowania.

\section{Artykuł 5 lit. a, b i d dyrektywy 2009/147/WE}

Artykuł 5 dyrektywy 2009/147/WE nakazuje państwom członkowskim ustanowienie powszechnego systemu ochrony dla wszystkich gatunków dzikiego ptactwa (z wyjątkiem określonych w załączniku II do tej dyrektywy gatunków łownych). System ochrony ma w szczególności zabraniać w odniesieniu do dzikiego ptactwa (a) umyślnego zabijania lub chwytania jakimikolwiek metodami; (b) umyślnego niszczenia lub uszkadzania ich gniazd i jaj lub usuwania ich gniazd; (d) umyślnego płoszenia, szczególnie w okresie lęgowym i wychowu młodych, jeśli mogłoby to mieć znaczenie w odniesieniu do celów dyrektywy ptasiej. System ochrony $\mathrm{w}$ danym państwie członkowskim ma obejmować wszystkie gatunki ptactwa występujące naturalnie w stanie dzikim na europejskim terytorium państw członkowskich, nie ograniczając się do dzikiego ptactwa, którego siedlisko naturalne znajduje się na jego terytorium. System ochrony ma więc obejmować również gatunki posiadające siedliska na terytorium innego lub innych państw członkowskich (wyrok TSUE w sprawie C-192/11, pkt 23-24, 33-34). Zgodnie z orzecznictwem TSUE art. 5 dyrektywy ptasiej wymaga, by państwa członkowskie ustanowiły kompletne i skuteczne ramy prawne poprzez podjęcie - jak przewiduje art. 12 dyrektywy siedliskowej - konkretnych i specyficznych środków ochrony, które mają pozwolić na zapewnienie skutecznego poszanowania wspomnianych wyżej zakazów zmierzających zasadniczo do chronienia terenów rozrodu i odpoczynku ptaków objętych tą dyrektywą (wyrok TSUE w sprawie C-441/17, pkt 252). Ochrona przewidziana w art. 5 lit. b musi mieć charakter stały i nie może zostać wyłączona w danych okresach. Konieczność taka wynika $\mathrm{z}$ faktu, że niektóre gatunki ponownie wykorzystują gniazda zbudowane w poprzednich latach (wyrok TSUE w sprawie 252/85). Okoliczność, że populacje określonych gatunków ptaków pozostają na niezmienionym poziomie, a nawet zwiększają się, jest bez znaczenia dla stwierdzenia naruszenia dyrektywy ptasiej. Obowiązki ochrony istnieją bowiem, zanim zostanie stwierdzone zmniejszenie liczby ptaków lub zanim zmaterializuje się ryzyko wyginięcia danego gatunku chronionego ptaków (wyrok TSUE w sprawie C-441/17 213). Powyższa interpretacja dotycząca ogólnego systemu ochrony ptaków przewidzianego w art. 4 ust. 4 dyrektywy ptasiej znajduje zastosowanie 
tym bardziej w ramach ochrony specjalnej przewidzianej w art. 5 lit. b i d dyrektywy ptasiej.

Dla prawidłowej interpretacji powyższych przepisów kluczowe jest wyjaśnienie znaczenia zastosowanego tam pojęcia „umyślności”. W świetle orzecznictwa TSUE należy uznać, że dotyczy ono sytuacji, w której sprawca albo zamierzał zabić ptaki należące do gatunku objętego ochroną, albo przynajmniej godził się na taką ewentualność ${ }^{14}$. Na zasadzie analogii trzeba zinterpretować pojęcie „umyślności" użyte w art. 5 lit. b i d ${ }^{15}$.

2.1. Artykuł 5 lit. a. Według analizowanej opinii, mimo formalnego objęcia na mocy prawa polskiego ochroną występujących w Polsce gatunków ptaków wymienionych w załączniku I do dyrektywy, wysokie prawdopodobieństwo pomyłki w identyfikacji gatunków podczas polowania prowadzi do naruszenia zakazu zabijania gatunków chronionych. Jak wskazuje Autorka, w szczególności podgorzałka zwyczajna (Aythya nyroca) może być mylona z kaczka czernica (Aythya fuligula) i głowienka zwyczajna (Aythya ferina). Natomiast gęś mała (Anser erythropus), bernikla biatolica (Branta leucopsis), bernikla rdzawoszyja (Branta ruficollis) moga być [...] mylone z gatunkami gęsi łownych.

Odnosząc się do powyższej tezy, należy zaznaczyć, że zgodnie z orzecznictwem TSUE przepisy dyrektywy muszą zostać wdrożone za pomocą instrumentów o niekwestionowanej mocy prawnej, a ponadto w sposób szczegółowy, precyzyjny i jasny, aby zapewnić poszanowanie zasady pewności prawa (wyrok TSUE w sprawie C-159/99, pkt 32). Sama tylko praktyka administracyjna, która może w ramach uznania zostać zmieniona przez organy krajowe, i która nie została w należyty sposób ogłoszona, nie może zostać uznana za prawidłowe wypełnienie obowiązków wynikających z dyrektyw (wyrok TSUE w sprawie C-75/01, pkt 28). W omawianym kontekście należy zwrócić uwagę na przepisy ustawy Prawo łowieckie, ustawy o ochronie przyrody i Kodeksu karnego. W myśl art. 42 Prawa łowieckiego uzyskanie uprawnień do wykonywania polowania wymaga spełnienia określonych warunków, w tym odbycia stażu, szkolenia i zdania egzaminu. Rozporządzenie Ministra Środowiska w sprawie uprawnień do wykonywania polowania (Dz.U. 2010, nr 3, poz. 19) przewiduje, że egzamin mający na celu uzyskanie podstawowych uprawnień do wykonywania polowania obejmuje sprawdzenie znajomości m.in. przepisów wskazanych w rozporządzeniu aktów prawnych, zasad i warunków wykonywania polowania, zasad ochrony przyrody i podstawowych gatunków zwierząt objętych ochroną gatunkową, listy gatunków zwierząt łownych, ich biologii oraz okresów polowań na te zwierzęta.

14 Wyrok TSUE w sprawie C-221/04, pkt 71 (interpretacja przyjęta na kanwie art. 12 ust. 1 lit. a dyrektywy siedliskowej).

15 Zob. przykładowo wyrok w sprawie C-103/00, gdzie TSUE uznał użytkowanie rowerów wodnych i małych łodzi za umyślne niepokojenie gatunków podczas okresu rozrodu (pkt 36). 
Prawo łowieckie określa również sankcje za naruszenie zawartych w nim zakazów, m.in. za wybieranie jaj, piskląt, niszczenie gniazd ptaków łownych lub ich lęgowisk (art. 51 ust. 1 pkt 2), jak również za polowanie w czasie ochronnym lub bez uprawnień do polowania (art. 53 pkt 3 i 4). Ponadto, zgodnie z art. 131 pkt 14 ustawy o ochronie przyrody: kto bez zezwolenia lub wbrew jego warunkom narusza zakazy w stosunku do roślin, zwierząt lub grzybów objętych ochrona gatunkowa podlega karze aresztu albo grzywny. Natomiast na mocy art. $181 \$ 3$ Kodeksu karnego grzywnie, karze ograniczenia wolności albo pozbawienia wolności do lat 2 podlega ten, kto niezależnie od miejsca czynu niszczy albo uszkadza rośliny lub zwierzęta pozostające pod ochroną gatunkową, powodując istotną szkodę. Należy zauważyć, że na mocy $\$ 5$ tego artykułu również sprawca działający nieumyślnie podlega karze, aczkolwiek w niższym wymiarze (grzywnie albo karze ograniczenia wolności). Wskazane przepisy mają na celu m.in. ochronę gatunków ptaków wskazanych w załączniku I dyrektywy ptasiej.

W świetle przywołanych przepisów należy uznać, że ustawodawca polski podjął działania zmierzające do zapewnienia ochrony wynikającej z art. 5 dyrektywy ptasiej poprzez wymóg poświadczenia znajomości gatunków chronionych i reguł ich ochrony, jak również poprzez ustanowienie sankcji o charakterze administracyjnym lub karnym za naruszenie tych reguł.

Analizowana opinia odnotowuje tę okoliczność, niemniej, w ocenie Autorki, zakazy te są nieskuteczne $z$ uwagi na prawdopodobieństwo pomyłki. W konsekwencji, celem uzyskania pełnej zgodności prawa łowieckiego z celami dyrektywy ptasiej należy wykreślić z listy ptaków łownych określone gatunki podobne do gatunków objętych ochroną.

W związku z tym należy zauważyć, że obowiązek wdrożenia (implementacji) dyrektywy nie ogranicza się do transpozycji, tj. przeniesienia norm dyrektywy do prawa krajowego. Obejmuje on bowiem konieczność podjęcia wszelkich innych działań, które zapewnią efektywne osiągnięcie celu określonego przez dyrektywę, w tym tzw. implementację konkretną, polegającą na efektywnym stosowaniu transponowanych norm w konkretnych przypadkach ${ }^{16}$. Dlatego też formalna transpozycja dyrektywy mogłaby istotnie zostać uznana za niewystarczającą, jeżeli w rzeczywistości cel dyrektywy nie mógłby w ten sposób zostać osiągnięty z powodów wskazanych w analizowanej opinii. W tym kontekście należy jednak zauważyć, że ustalając treść załącznika II do dyrektywy, uwzględnia takie czynniki, jak zagrożenie dla gatunków chronionych wynikające z ich podobieństwa do gatunków łownych. Przykładowo, na mocy dyrektywy 94/24/WE z 8 czerwca 1994 r. zmieniającej załącznik II do dyrektywy 74/409/EWG w sprawie ochrony dzikiego ptactwa Rada usunęła z załącznika II/2 gatunki Limosa limosa, Limosa lapponica oraz Numenius arquata w odniesieniu do Włoch w celu ochrony glo-

16 B. Kurcz, Dyrektywy Wspólnoty Europejskiej i ich implementacja do prawa krajowego, Kraków 2004, s. 46, 49. 
balnie zagrożonego gatunku Numenius tnuirostis, do którego wskazane gatunki są tak bardzo podobne, jeśli chodzi o ich zwyczaje i wygląd, że istnieje szczególne ryzyko ich pomylenia ${ }^{17}$. Wobec powyższego można więc uznać, że w przypadku gatunków nadal figurujących w załączniku II unijny prawodawca nie podziela wyrażonego w analizowanej opinii poglądu o konieczności usunięcia wskazanych gatunków z listy gatunków łownych w skali Polski.

Natomiast należy zgodzić się, że podnoszony w analizowanej opinii problem ma potencjalnie poważny charakter i prawidłowe wdrożenie dyrektywy może wymagać wprowadzenia postulowanych w niej ograniczeń w skali lokalnej, z uwzględnieniem takich czynników jak rzeczywiste podobieństwo danych gatunków, prawdopodobieństwo wystąpienia pomyłki czy względnie znaczne występowanie podobnych gatunków w tym samym czasie i miejscu objętym polowaniem. Trzeba też podkreślić, że wprowadzenie zakazu polowania nie zawsze stanowiłoby środek konieczny. W zależności bowiem od sytuacji dla zapewnienia zgodności z dyrektywą może okazać się wystarczające np. odpowiednie określenie godzin polowania, co poprawi widoczność i rozpoznawalność ptaków.

Na problem pomylenia gatunków łownych i gatunków objętych ochroną zwraca również uwagę Komisja Europejska, przy czym w jej wytycznych proponuje się rozwiązania o charakterze lokalnym: ryzyko pomyłki [...] może stanowić ryzyko dla ochrony niektórych narażonych lub zagrożonych gatunków [...] szczególnie na obszarach, gdzie odbywa się polowanie. Problemem tym należałoby się zajać w ogólnym kontekście gospodarki tymi terenami (wytyczne 2008, pkt 2.6.10).

2.2. Artykuł 5 lit. b. Analizowana opinia nie uzasadnia tezy o niezgodności $\mathrm{z}$ art. 5 lit. $\mathrm{b}$ dyrektywy.

2.3. Artykuł 5 lit. d. Odnosząc się do tezy, zgodnie z którą polowania odbywające się w siedliskach gatunków chronionych mogą stanowić naruszenie zakazu umyślnego płoszenia tych ptaków, szczególnie w okresie lęgowym i wychowu młodych, a w konsekwencji naruszenie art. 5 lit. d, należy odesłać do uwag dotyczących art. 4 ust. 4 dyrektywy ptasiej. Wynika z nich, że prowadzenie polowań (również w siedliskach gatunków chronionych) jest dopuszczalne, natomiast wprowadzenie zakazów lub ograniczeń w tym zakresie powinno odbywać się z uwzględnieniem okoliczności danego przypadku.

\section{Naruszenie art. 6 lit. a, b i c konwencji berneńskiej}

Artykuł 6 lit. a, b i c konwencji berneńskiej wymaga, aby państwa strony konwencji wprowadziły zakaz następujących działań w odniesieniu do gatunków dzikiej fauny, wymienionych w załączniku II do konwencji: (a) wszystkich form umyślnego chwytania, przetrzymywania i umyślnego zabijania; (b) umyślnego uszkadzania lub niszczenia miejsc rozrodu lub odpoczynku; (c) umyślnego nie-

17 Zob. preambuła dyrektywy 94/24/WE. 
pokojenia dzikich zwierząt, zwłaszcza w okresie rozrodu, wychowu młodych lub snu zimowego, jeżeli takie postępowanie będzie miało istotne skutki w odniesieniu do celów niniejszej konwencji.

Z uwagi na podobieństwo między art. 6 lit. a, b i c konwencji berneńskiej a art. 5 lit a, b, d dyrektywy ptasiej można uznać, że zawarte wyżej uwagi dotyczące w tym zakresie tej dyrektywy znajdują odniesienie również do odpowiednich przepisów konwencji berneńskiej.

\section{Opiniowana teza: „brak szacowania liczebności stanu większości gatunków ptaków łownych na obszarze obwodów łowieckich, na których następuje ich pozyskiwane, prowadzi do naruszenia art. 7 ust. 4 dyrektywy"}

Jak wskazuje się w analizowanej opinii, w odniesieniu do większości gatunków ptaków, w tym także gatunków niemigrujących, nie określa się ich liczebności, a jedynie pozyskanie, co stanowi naruszenie art. 7 ust. 4 dyrektywy ptasiej. Zgodnie $\mathrm{z}$ analizowaną opinią prowadzi to do naruszenia art. 7 ust. 4 dyrektywy (zasada rozsądnego wykorzystywania i ekologicznie zrównoważonej kontroli gatunków). Nie może być bowiem mowy o rozsądnym wykorzystywaniu i ekologicznie zrównoważonej kontroli gatunków bez znajomości elementarnych danych o ilości eksploatowanych zasobów.

Należy zgodzić się z Autorką, że: unijny wymóg rozsądnego wykorzystywania $i$ ekologicznie zrównoważonej kontroli zakłada posiadanie elementarnych danych odnośnie stanu zasobów, którymi sie gospodaruje. Znajduje to potwierdzenie m.in. w wytycznych KE z 2008 r., gdzie zauważa się, że: istnieje potrzeba solidnych, opartych na naukowych podstawach mechanizmów monitorowania w celu zapewnienia, aby wykorzystywanie było utrzymane na poziomach, które moga być znoszone przez populacje dzikich gatunków nie wpływając szkodliwie na rolę gatunków $w$ ekosystemie lub na sam ekosystem (wytyczne 2008, pkt 2.4.16), a także że: plany gospodarowania majace na celu przywrócenie właściwego stanu zachowania gatunków musza być poparte programami monitorowania zdolnymi do wykrycia zmian $w$ stanie zachowania odnośnych gatunków. Monitorowanie to powinno obejmować ocene odłowu w ramach polowania oraz roli, jaka petni on w dynamice populacji (wytyczne 2008, pkt 2.4.28).

Jednocześnie jednak trzeba zauważyć, że zgodnie z art. 8a ust. 2 ustawy - Prawo łowieckie inwentaryzacja zwierzyny ma być sporządzana rokrocznie przez dzierżawców albo zarządców obwodów łowieckich i ma zawierać szacowaną liczebność występujących zwierząt łownych (z wyłączeniem łownych ptaków migrujących). Analizowana opinia uwzględnia treść tego przepisu, jednak zauważa się tam, że: $w$ odniesieniu do większości gatunków ptaków, w tym także gatunków nie migrujących, nie określa się ich liczebności a jedynie pozyskanie. Wynika 
to $z$ art. 8a. 2 ustawy - prawo łowieckie [który - M.J.] stanowi: „Inwentaryzacja zwierzyny [...] zawiera szacowana liczebność występujących zwierząt łownych, $z$ wyłaczeniem łownych ptaków migrujących [...]" oraz $z$ zatwierdzonego przez Ministra Środowiska wzoru rocznego planu łowieckiego, który zawiera znaki X (nie należy wypetniać) w rubrykach dotyczacych szacowanej liczebności: gęsi gęgawy, gęsi zbożowej i gęsi białoczelnej, krzyżówki, cyraneczki, głowienki, czernicy, gołębia grzywacza, słonki i tyski.

Odnosząc się do powyższej tezy, należy uznać, że na poziomie ustawowym wymóg inwentaryzacji został zrealizowany, zaś wyłączenie spod niego ptaków migrujących wiąże się z brakiem praktycznej możliwości wiarygodnego oszacowania ich liczebności na potrzeby planowania gospodarki łowieckiej. Ocena wskazanego $\mathrm{w}$ analizowanej opinii formularza wykracza natomiast poza granice niniejszej opinii.

\section{Opiniowana teza: „zbyt krótkie okresy ochronne dla gatunków głowienki (Aythya ferina), czernicy (Aythya fuligula), łyski (Fulica atra), gołębia grzywacza (Columba palumbus) i gęsi gęgawy (Anser anser) stanowią naruszenie art. 7 ust. 4 dyrektywy ptasiej"}

Zgodnie z art. 7 ust. 4 dyrektywy ptasiej państwa członkowskie zapewniają, by na gatunki, do których stosuje się prawo łowieckie, nie były organizowane polowania w okresie wychowu młodych ani w czasie trwania poszczególnych faz reprodukcji (akapit 2), zaś w przypadku gatunków wędrownych - by na gatunki, do których mają zastosowanie przepisy łowieckie, nie były organizowane polowania w okresie ich reprodukcji lub ich powrotu do swoich miejsc wylęgu (akapit 3). Zgodnie $\mathrm{z}$ utrwalonym orzecznictwem TSUE przepisy te zmierzają do zapewnienia systemu całkowitej ochrony w okresach szczególnego narażenia ptaków. Niezgodne $\mathrm{z}$ art. 7 ust. 4 dyrektywy ptasiej byłoby więc wyznaczenie okresów ochronnych na podstawie okresów reprodukcji czy wędrówek typowych dla większości osobników danego gatunku. Prowadziłoby to bowiem do wyłączenia części populacji spod ochrony z uwagi na wariacje wynikające w szczególności ze zmiennych warunków meteorologicznych ${ }^{18}$.

Powołując się na opracowanie P. Wylegały i Ł. Ławickiego ${ }^{19}$, Autorka analizowanej opinii wskazuje, że: okres wychowu młodych u głowienki, czernicy, łyski i grzywacza kończy się między pierwsza dekada września a końcem miesiąca, podczas gdy sezon polowania na te gatunki rozpoczyna sie już 15 sierpnia. W ocenie

18 Wyrok TSUE w sprawie C-157/89, pkt 14.

19 P. Wylegała, Ł. Ławicki, Głowienka, czernica, cyraneczka, łyska - stan populacji w Polsce $i$ wpływ gospodarki łowieckiej. Opinia na potrzeby Polskiego Komitetu Krajowego IUCN, PTOP Salamandra, Poznań 2019. 
Autorki sytuację taką należy w związku z tym uznać za naruszenie art. 7 ust. 4 dyrektywy ptasiej. Analiza fachowej literatury z zakresu ornitologii wykracza poza przedmiot niniejszej opinii. Należy jednak zauważyć, że zgodnie z materiałem „Key Concepts Document on Article 7(4)” dostępnym na stronie Komisji Europejskiej ${ }^{20}$, okres reprodukcji (z uwzględnieniem wychowu młodych) wskazanych gatunków na terytorium Polski kończy się w ostatniej dekadzie lipca (gołąb grzywacz, łyska), w drugiej dekadzie sierpnia (głowienka) lub w końcu sierpnia (czernica, gęgawa) ${ }^{21}$.

W analizowanej opinii wskazuje się również, że: na terenie województw dolnośląskiego, lubuskiego, wielkopolskiego i zachodniopomorskiego okres polowań na gessi zbożowe i białoczelne jest wydłużony do 31 stycznia, a na gegawy do 15 stycznia. Określone we wzmiankowanym rozporzadzeniu terminy narażaja więc gęsi gegawy na przypadkowe zastrzelenie $w$ drugiej połowie stycznia $w$ wyniku pomyłki z gęsia zbożowa lub białoczelną. W ocenie Autorki stanowi to naruszenie art. 7 ust. 4 dyrektywy ptasiej.

Odnosząc się do powyższej tezy, należy odwołać się do stanowiska TSUE wyrażonego w sprawie C-435/92. Komentując zagrożenie gatunków migrujących z uwagi na ich podobieństwo do gatunków, na które sezon polowań jeszcze się nie zakończył, TSUE uznał, że art. 7 ust. 4 (akapit 3) dyrektywy ptasiej ma służyć m.in. ochronie takich gatunków przed zagrożeniem związanym z polowaniami mającymi miejsce $\mathrm{w}$ trakcie ich migracji przedgodowych. Wymaga to więc ze strony państw członkowskich podjęcia wszelkich niezbędnych środków w celu zapobieżenia polowaniom w takim okresie (wyrok TSUE w sprawie C-435/92, pkt 18). Należy też zaznaczyć, że określenie różnych dat zakończenia okresu polowania dla różnych regionów danego państwa członkowskiego jest dopuszczalne, jednak pod warunkiem zapewnienia pełnej ochrony ptakom migrującym (wyrok TSUE w sprawie C-435/92, pkt 27).

Interpretując ten wyrok, Komisja Europejska zauważa m.in., że (a) jeżeli zróżnicowanie terminów polowań ma być dozwolone, to terminy otwarcia i zamknięcia muszą być ustalane dla każdej grupy „podobnych” gatunków w sposób uniemożliwiający ich częściowe pokrywanie się z okresami, w czasie których, zgodnie z dyrektywą, polowania są niedozwolone; (b) aby ryzyko było realne, gatunki łowne (lub ich grupy) muszą występować na obszarze objętym polowaniem w danych ramach czasowych, zaś obecność innych, „mylących” gatunków łownych, dla których okres polowań jest zamknięty, również powinna być przewidywalna i znaczna; (c) ryzyko pomyłki zwiększa fakt, że różne gatunki pta-

20 Https://ec.europa.eu/environment/nature/conservation/wildbirds/action_plans/guidance_en.htm.

21 Dane dla poszczególnych gatunków są ujęte zbiorczo dla całych państw członkowskich i nie uwzględniają ewentualnych rozbieżności na poziomie regionalnym. Opracowanie uwzględnia najpóźniejsze daty w danym państwie członkowskim (s. 7). 
ków często współistnieją, w związku z czym polowanie selektywne może stać się bardzo trudne. Komisja wskazuje też, że należy uwzględnić takie czynniki wpływające na ryzyko wystąpienia pomyłki, jak typ polowania i związana $\mathrm{z}$ tym przewidywana odległość ptaków od myśliwego, pora polowania, warunki atmosferyczne i wynikające $\mathrm{z}$ nich ograniczenia widoczności, a także kompetencje myśliwego. W konsekwencji Komisja widzi konieczność przeprowadzenia podziału na grupy „podobnych” gatunków łownych używających tych samych typów siedlisk w tym samym czasie oraz ustalenia tych samych terminów otwarcia i zamknięcia dla polowań na te grupy w taki sposób, aby uniknąć kolidowania ich z okresami, gdy polowanie jest niedozwolone. Wymaga to także ustalenia, czy warunki, w jakich odbywa się polowanie, nie stwarzają poważnego ryzyka pomyłki różnych gatunków łownych (wytyczne 2008, pkt 2.6.3-2.6.13, 2.6.24).

W odniesieniu do potencjalnego wpływu ludzkiego zakłócenia na populacje ptaków w okresie zróżnicowanych terminów polowań, Komisja Europejska preferuje podejście zniuansowane. Polega ono na uwzględnieniu potrzeby stworzenia dodatkowych niezakłóconych obszarów schronienia, które zapewnią ptakom narażonym na zakłócenia zarówno odpoczynek, jak i pożywienie. Projekt takich obszarów musi stwarzać możliwość dobrego jakościowo żerowania oraz innych rodzajów aktywności w ich obrębie. Należy to określić dla każdego obszaru z osobna w odniesieniu do ekologicznych, behawioralnych, żywieniowych i energetycznych potrzeb różnych gatunków łownych, na które mają wpływ zróżnicowane terminy polowań (wytyczne 2008, pkt 2.6.220).

Podsumowując, należy stwierdzić, że ocena zasadności tezy zawartej w analizowanej opinii powinna zostać przeprowadzona dla danego obszaru z uwzględnieniem wskazanych wyżej elementów szczegółowo określonych w wytycznych 2008.

\section{Opiniowana teza: „stosowanie śrutu ołowianego stanowi naruszenie art. 4 ust. 4 dyrektywy ptasiej oraz art. 6 lit. b i c konwencji berneńskiej"}

W analizowanej opinii wskazuje się, że stosowanie przez myśliwych śrutu ołowianego stanowi naruszenie art. 4 ust. 4 dyrektywy ptasiej (jako wywołujące powstawanie zanieczyszczenia lub pogorszenie warunków naturalnych siedlisk lub zakłócenie wpływające na ptactwo), a także art. 6 lit. b i c konwencji berneńskiej (umyślne uszkadzanie lub niszczenie miejsc rozrodu lub odpoczynku; umyślne niepokojenie dzikich zwierząt, zwłaszcza w okresie rozrodu, wychowu młodych lub snu zimowego), ponieważ jest to metal ciężki, który nie ulega biodegradacji, kumuluje się natomiast w tkankach organizmów żywych. Stosowanie tego rodzaju amunicji podczas polowań powoduje, że w siedlisku pozostawiany jest toksyczny śrut ołowiany, który przenika do środowiska wodnego, pogarszając warunki ekologiczne bytowania ptaków chronionych. 
Stosowanie amunicji ołowianej nie jest wprost uregulowane ani przez dyrektywę ptasią, ani przez konwencję berneńską ${ }^{22}$. Niemniej w zaleceniu przyjętym przez Stały Komitet w ramach tej konwencji wskazuje się na zwiększoną śmiertelność wśród ptactwa wodnego i drapieżników wywołaną zatruciem ołowiem, w większości pochodzącym z amunicji. W konsekwencji Stały Komitet zaleca podjęcie działań zmierzających do bezzwłocznego zakończenia stosowania śrutu ołowianego na terenach podmokłych, a także określenie harmonogramu zastąpienia śrutu ołowianego śrutem wytworzonym z materiałów nietoksycznych ${ }^{23}$.

Również w dokumentach KE zagadnienie toksyczności amunicji podnoszone jest od lat. Można tu wskazać na komunikat KE z 29 maja 1995 r. Wise use and conservation of wetlands (COM (95) 189 final), w którym zauważa się, że zasada wykorzystywania zasobów ptactwa wodnego w zrównoważony sposób może istotnie przyczyniać się do ochrony terenów wodno-błotnych, pod warunkiem że obejmuje używanie nietoksycznego śrutu (s. 15), oraz, że wysoce pożądane byłoby przyjęcie na poziomie UE aktu zmierzającego do eliminacji toksycznego śrutu (przypis 28 komunikatu). W wytycznych 2008 Komisja Europejska wskazuje, że coraz powszechniej uznaje się, iż używanie ołowianego śrutu stwarza istotne zagrożenie dla ptaków i ich siedlisk, zwłaszcza terenów wodno-błotnych. Jego stosowanie na obszarach szczególnej ochrony, które prowadzi do pogorszenia stanu siedlisk lub poważnego zakłócenia dla ptaków, jest niezgodne z wymogami ochrony tych terenów (wytyczne 2008, pkt 2.4.18-2.4.19).

Należy też zauważyć intensyfikację działań KE w tym zakresie od roku 2015. W szczególności trzeba zwrócić uwagę na następujące dokumenty sporządzone na wniosek KE przez Europejską Agencję Chemikaliów (ECHA):

- sprawozdanie z kwietnia 2017 r. zawierające projekt wprowadzenia ograniczenia możliwości stosowania śrutu ołowianego na terenach podmokłych. W czerwcu 2018 r. opinia komitetów naukowych ECHA została przedłożona Komisji Europejskiej i obecnie dokument ten jest przedmiotem jej prac,

- sprawozdanie z września 2018 r. (wersja skorygowana z listopada 2018 r.) ) $^{24}$ zawierające m.in. propozycję ograniczenia możliwości stosowania amunicji ołowianej również na pozostałych terenach. Obecnie toczą się dalsze prace nad tym dokumentem (w okresie październik-grudzień 2019 r. trwało zgłaszanie uwag w ramach konsultacji prowadzonych przez Europejską Agencję

22 W odróżnieniu od porozumienia o ochronie afrykańsko-euroazjatyckich wędrownych ptaków wodnych, które przewiduje, że strony podejmą działania zmierzające do zaprzestania stosowania śrutu ołowianego na terenach podmokłych (załącznik 3, pkt 4.1.4). Stronami porozumienia są m.in. Unia Europejska oraz większość państw członkowskich UE, poza Austrią, Grecją, Maltą i Polską.

23 Zalecenie Stałego Komitetu z 6 grudnia 1991 r. w sprawie stosowania nietoksycznego śrutu na terenach podmokłych.

24 Annex XV Investigation Report A review of the available information on lead in shot used in terrestrial environments, in ammunition and in fishing tackle. 
Chemikaliów). W ocenie ECHA akt prawny może zostać przyjęty do końca 2022 r., o ile uda się osiągnąć porozumienie $\mathrm{w}$ ramach procedury ustawodawczej ${ }^{25}$.

Odnosząc się do prawnej możliwości stosowania śrutu ołowianego w świetle obecnie obowiązujących przepisów, należy zauważyć, że zarówno konwencja berneńska, jak i dyrektywa ptasia dopuszczają prowadzenie polowań. W związku $\mathrm{z}$ tym należy rozważyć, czy w ten (dorozumiany) sposób oba akty prawne dopuszczają stosowanie amunicji ołowianej na chronionych obszarach. Konkluzje sprawozdań ECHA każą jednak zakwestionować taki argument. W dokumentach tych bowiem nie tylko wskazuje się, że wyniki badań potwierdzają szkodliwość ołowiu dla (m.in.) ptaków, zarówno na terenach podmokłych, jak i pozostałych ${ }^{26}$. Wynika z nich również, że w powszechnym użyciu w UE, jak i poza nią, jest śrut $\mathrm{z}$ innych materiałów (głównie stalowy i bizmutowy, ale również wolframowy). $\mathrm{W}$ sprawozdaniu wskazuje się, że stosowanie śrutu $\mathrm{z}$ alternatywnych materiałów jest technicznie wykonalne, porównywalne cenowo, a jednocześnie mniej szkodliwe dla środowiska ${ }^{27}$. Dopuszczalność prowadzenia polowań nie implikuje więc możliwości stosowania śrutu ołowianego. W świetle przywołanych wyników badań naukowych uzasadniona wydaje się teza, że stosowanie śrutu ołowianego na obszarach szczególnej ochrony może zostać uznane za niezgodne z wymogami ochrony tych terenów.

\section{Opiniowana teza: „polowania na bażanty i kuropatwy hodowane w ośrodkach hodowli zwierzyny stanowią naruszenie rozporządzenia Rady nr 1099/2009 z 24 września 2009 r. w sprawie ochrony zwierząt podczas ich uśmiercania"}

W analizowanej opinii wskazuje się, że bażanty i kuropatwy hodowane w ośrodkach hodowli zwierzyny (OHZ) traktowane są jak ptaki gospodarskie, w związku z czym objęte są wymogami, o których mowa w rozporządzeniu 1099/2009.

25 Https://echa.europa.eu/hot-topics/lead-in-shot-bullets-and-fishing-weights.

26 Sprawozdanie ECHA z września 2018, s. 7-9.

27 Sprawozdanie ECHA $\mathrm{z}$ kwietnia 2017 (ANNEX XV RESTRICTION REPORT PROPOSAL FOR A RESTRICTION SUBSTANCE NAME: Lead EC NUMBER: 231-1004 CAS NUMBER: 7439-92-1, s. 65). Jednocześnie należy jednak zauważyć, że w literaturze wskazuje się również na niedoszacowanie ryzyka ekologicznego związanego $\mathrm{z}$ uwalnianiem metali ze śrutu wytworzonego $\mathrm{z}$ alternatywnych wobec ołowiu materiałów i w konsekwencji postuluje się prowadzenie dalszych badań nad ich toksycznością [szerzej zob. J. Fäth i in., Leaching behavior and ecotoxicological effects of different game shot materials in freshwater, "Knowledge \& Management of Aquatic Ecosystems" 2018, No 419(24)]. 
W szczególności powinny one być uśmiercane wyłącznie po uprzednim ogłuszeniu, zgodnie z metodami określonymi dla drobiu w załączniku I rozporządzenia. W świetle analizowanej opinii bażanty i kuropatwy hodowane w OHZ stają się zwierzyną łowną dopiero po wypuszczeniu ich na wolność do docelowych siedlisk i łowisk, w których przetrwają do czasu wyprowadzenia własnych lęgów - stają się wówczas zwierzyną dziką i dopiero wtedy mogą zostać uznane za zwierzynę łowną. Autorka analizowanej opinii zwraca uwagę, że choć rozporządzenia nie stosuje się do polowań, to wyłączenie to należy rozumieć jako dotyczące polowań na zwierzynę wolno żyjącą, w stanie dzikim.

Istotnie, rozporządzenie 1099/2009 nie znajduje zastosowania podczas polowań (art. 3 lit. a pkt ii tego rozporządzenia), jednak samo pojęcie „polowania” nie zostało w nim zdefiniowane. W preambule wskazuje się jedynie uzasadnienie powyższego wyłączenia. Zgodnie z jej motywem (14) polowania odbywają się w kontekście, którego warunki w odniesieniu do uśmiercania znacznie się różnią od stosowanych wobec zwierząt utrzymywanych w warunkach fermowych, a łowiectwo podlega szczególnemu prawodawstwu.

W sytuacji, w której akt prawa UE nie definiuje określonego pojęcia w sposób autonomiczny, należy oprzeć się na definicji przyjętej w prawie państwa członkowskiego. Zgodnie z art. 4 ust. 2 ustawy - Prawo łowieckie, termin „polowanie” oznacza: tropienie, strzelanie z myśliwskiej broni palnej, łowienie sposobami dozwolonymi zwierzyny żywej, (a także, za zgodą ministra właściwego do spraw środowiska, łowienie zwierzyny przy pomocy ptaków łowczych) zmierzające do wejścia w jej posiadanie. Z kolei pojęcie „zwierzyna” oznacza zwierzęta łowne (art. 1 prawa łowieckiego). W literaturze wskazuje się, że pojęcie „zwierzyna łowna” zostało użyte we wskazanym przypisie w sensie prawnym, jest ono zmienne w czasie oraz w ogóle nie pokrywa się z pojęciem stosowanym w naukach łowieckich, biologii i naukach przyrodniczych ${ }^{28}$. Aktualnie wykaz gatunków zwierząt łownych jest zawarty w rozporządzeniu Ministra Środowiska z 11 marca 2005 r. w sprawie ustalenia listy gatunków zwierząt łownych (Dz.U. nr 45, poz. 433) i obejmuje m.in. bażanty i kuropatwy. Wskazuje się też, że w odróżnieniu od ustawy łowieckiej z 1959 r. obecna ustawa - Prawo łowieckie nie zastrzega, że termin „polowanie” nie obejmuje czynności zmierzających do pozyskania zwierzyny podejmowanych $\mathrm{w}$ ogrodzonych zwierzyńcach, bażantarniach, parkach narodowych i niektórych rezerwatach przyrody. Można z tego wysnuć wniosek, że w świetle obowiązujących przepisów czynności podejmowane na takich terenach są uważane za polowanie ${ }^{29}$.

Odnosząc powyższe ustalenia do zaprezentowanej w analizowanej opinii tezy, zgodnie z którą bażanty i kuropatwy mogą zostać uznane za zwierzynę

28 W. Radecki, Prawo łowieckie - komentarz, Warszawa 2014, s. 57-58; B. Rakoczy, R. Stec, A. Woźniak, Prawo łowieckie. Komentarz, 2014, LEX.

29 W. Radecki, Prawo łowieckie, op. cit., s. 69. 
łowną dopiero po okresie wyprowadzenia własnych lęgów, należy uznać, że jest ona zbyt daleko idąca i nadmiernie zawęża interpretację pojęcia "polowanie”, w konsekwencji bezpodstawnie poszerzając zakres stosowania rozporządzenia 1099/2009.

\section{Opiniowana teza: „brak przeprowadzania procedury strategicznej oceny oddziaływania na środowisko wieloletnich planów hodowlanych oraz rocznych planów łowieckich narusza art. 14 ust. 1 lit. a konwencji o różnorodności biologicznej, art. 6 ust. 3 dyrektywy siedliskowej, art. 46 pkt 3 ustawy o udostępnianiu informacji o środowisku i jego ochronie, udziale społeczeństwa w ochronie środowiska oraz o ocenach oddziaływania na środowisko oraz art. 33 ust. 3 ustawy o ochronie przyrody"}

Zgodnie z analizowaną opinią łowiectwo jest działalnością istotnie oddziałującą na środowisko i jako takie może być realizowane tylko na podstawie dokumentów planistycznych podlegających ocenie środowiskowej z uwzględnieniem czynnika udziału społecznego. Wieloletni plan hodowlany oraz roczne plany łowieckie są dokumentami, których realizacja może negatywnie wpływać na środowisko przyrodnicze, wymagającymi przeprowadzenia strategicznej oceny oddziaływania na środowisko. Tymczasem, mimo przyjęcia $\mathrm{w}$ ustawodawstwie polskim przepisów dotyczących ocen oddziaływania na obszary Natura 2000 (w szczególności art. 46 ust. 1 pkt 3 ustawy o udostępnianiu informacji o środowisku i jego ochronie, udziale społeczeństwa $\mathrm{w}$ ochronie środowiska oraz o ocenach oddziaływania na środowisko oraz art. 33 ust. 3 ustawy o ochronie przyrody), w analizowanej opinii wskazuje się, że w Polsce procedura zatwierdzania rocznych planów łowieckich i wieloletnich łowieckich planów hodowlanych nie uwzględnia tych przepisów.

Konwencja o różnorodności biologicznej została zawarta 5 czerwca 1992 r. i weszła w życie 29 grudnia 1993 r. Stronami tej konwencji są m.in. Polska oraz Unia Europejska. Artykuł 14 konwencji nakłada na strony - w miarę możliwości i potrzeb - obowiązek m.in. (a) wprowadzenia procedur wymagających wykonania oceny oddziaływania na środowisko proponowanych projektów, które mogą mieć istotne negatywne skutki dla różnorodności biologicznej, w celu uniknięcia lub zmniejszenia takich skutków, oraz tam, gdzie to jest właściwe, pozwala na udział społeczności w tych procedurach; (b) wprowadzenia uregulowań dla zapewnienia, że środowiskowe konsekwencje jej programów i polityk, które mogą mieć znacznie negatywne oddziaływanie na różnorodność biologiczną, są w sposób należyty brane pod uwagę. 
Jednym z instrumentów prawnych wdrażających konwencję o różnorodności biologicznej na poziomie UE jest dyrektywa siedliskowa ${ }^{30}$. Jej art. 6 ust. 3 przewiduje więc obowiązki podobne do tych wynikających $\mathrm{z}$ art. 14 konwencji o różnorodności biologicznej. Przepis ten wymaga, aby państwa członkowskie UE wprowadziły w życie regulacje przewidujące, że każdy plan lub przedsięwzięcie, które nie jest bezpośrednio związane lub konieczne do zagospodarowania terenu, ale które może na nie w istotny sposób oddziaływać, zarówno oddzielnie, jak i w połączeniu z innymi planami lub przedsięwzięciami, podlegało odpowiedniej ocenie jego skutków dla danego terenu z punktu widzenia założeń jego ochrony. Państwa członkowskie wyrażają zgodę na ten plan lub przedsięwzięcie dopiero po upewnieniu się, że nie wpłynie on niekorzystnie na dany teren oraz, w stosownych przypadkach, po uzyskaniu opinii całego społeczeństwa.

Dyrektywa siedliskowa nie definiuje pojęć „plan” ani „przedsięwzięcie”. W zawiadomieniu Komisji Europejskiej z 21 listopada 2018 r. „Zarządzanie obszarami Natura 2000. Przepisy art. 6 dyrektywy siedliskowej 92/43/EWG” (dalej: „zawiadomienie 2018”) sugerowane jest szerokie rozumienie tych pojęć, ponieważ dyrektywa siedliskowa nie ogranicza zakresu ani planu, ani przedsięwzięcia poprzez odwołanie się do konkretnych ich kategorii. Głównym czynnikiem ograniczającym jest natomiast to, czy mogą one w istotny sposób oddziaływać na obszar. W ocenie Komisji Europejskiej zakres art. 6 ust. 3 obejmuje również plany sektorowe, o ile mogą one oddziaływać w sposób istotny na obszary Natura 2000. Mogą to być na przykład plany sieci transportowych, plany energetyczne, plany gospodarki odpadami, plany gospodarki wodnej lub plany gospodarki leśnej (pkt 3.4 zawiadomienia 2018). Konieczność przeprowadzenia oceny skutków powstaje, jeżeli istnieje prawdopodobieństwo lub ryzyko, że ten plan lub przedsięwzięcie będzie oddziaływać na dany teren w istotny sposób. W orzecznictwie TSUE przyjęto szeroką interpretację obowiązku określonego w art. 6 ust. 3 dyrektywy siedliskowej: Mając w szczególności na uwadze zasadę ostrożności, będąca jedna z podstaw polityki Wspólnoty $w$ dziedzinie środowiska naturalnego, stawiajacej sobie za cel wysoki poziom ochrony zgodnie z art. 174 ust. 2 zdanie pierwsze WE, w świetle którego należy dokonywać wykładni dyrektywy siedliskowej, ryzyko takie ma miejsce wówczas, gdy na podstawie obiektywnych informacji nie można wykluczyć, że przedmiotowy plan lub przedsięwzięcie będzie oddziaływać na dany teren w istotny sposób (wyrok TSUE w sprawie C-127/02, pkt 44). Z kolei w odniesieniu do pojęcia „istotne oddziaływanie" TSUE podkreślił, że jest ono związane z założeniami ochrony danego terenu. Jeżeli plan wpływa na dany teren, jednakże nie niesie ze sobą ryzyka naruszenia założeń ochrony tego terenu, to nie należy tego planu lub przedsięwzięcia traktować jako mogącego oddziaływać na przedmiotowy teren w sposób istotny.

30 Zob. szerzej J.M. Verschuuren, Implementation of the Convention on Biodiversity in Europe: 10 Years of Experience with the Habitats Directive, „Journal of International Wildlife Law and Policy“ 2002, No 5, s. 251. 
Jeżeli natomiast niesie on ze sobą ryzyko naruszenia założeń ochrony tego terenu, należy go wówczas konsekwentnie uznać za mogący oddziaływać na przedmiotowy teren w sposób istotny (wyrok TSUE w sprawie C-127/02, pkt 46-48).

Zgodnie $\mathrm{z}$ orzecznictwem TSUE niezgodna $\mathrm{z}$ art. 6 ust. 2 i 3 dyrektywy siedliskowej jest możliwość całkowitego zwolnienia pewnych rodzajów działalności na podstawie obowiązujących przepisów z obowiązku oceny oddziaływania na dany teren. Takie zwolnienie nie może bowiem zagwarantować, że działalność tego rodzaju nie będzie miała niekorzystnego wpływu na ten obszar (wyrok TSUE w sprawie C-98/03 pkt 43, 44; wyrok TSUE w sprawie C-241/08, pkt 31). $\mathrm{Z}$ uwagi na przedmiot niniejszej opinii należy zwrócić uwagę na wyrok w sprawie C-241/08, w którym TSUE uznał, że francuski przepis apriorycznie przesądzający, że polowanie i inna działalność łowiecka, które są podejmowane na warunkach dopuszczalnych na podstawie obowiązujących ustaw i przepisów wykonawczych i na określonych $\mathrm{w}$ tych przepisach terenach, nie stanowią działalności będącej niepokojeniem lub oddziałującej w ten sposób ${ }^{31}$, był niezgodny z art. 6 ust. 2 i 3 dyrektywy siedliskowej (wyrok TSUE w sprawie C-241/08, pkt 30-39). W świetle przywołanego orzecznictwa za niezgodną z dyrektywą siedliskową należy uznać w szczególności interpretację (w tym wypadku ustawy o ochronie przyrody), zgodnie z którą działalność łowiecka nie może poważnie negatywnie oddziaływać na cele ochrony obszaru Natura 2000, ponieważ godziłoby to w podstawowe cele, jakim ma służyć łowiectwo ${ }^{32}$. Taka interpretacja koliduje bowiem $\mathrm{z}$ - wynikającym z art. 4 ust. 3 Traktatu o Unii Europejskiej wymogiem interpretacji prawa krajowego, w miarę możliwości, w sposób zgodny z prawem UE. Zgodnie $z$ orzecznictwem TSUE, stosując prawo wewnętrzne, a w szczególności przepisy prawa krajowego wprowadzone w celu wykonania dyrektywy, sądy krajowe są zobowiązane do wykładni prawa krajowego zgodnie $\mathrm{z}$ treścią i celem dyrektywy, w celu osiągnięcia rezultatu, o którym mowa w art. 288 akapit trzeci TFUE (wyrok TSUE w sprawie 14/83, pkt 26).

Konkludując, należy stwierdzić, że praktyka polegająca na generalnym wyłączeniu planów łowieckich spod wymogu poddania ocenie wpływu na dany teren, o której mowa w art. 6 ust. 3 dyrektywy siedliskowej, może zostać uznana za niezgodną z tym przepisem.

31 Ówczesny art. L. 414-1 ust. V code de l'environnement (francuskiego kodeksu ochrony środowiska naturalnego).

32 Przyjęcie zgodnie $z$ ustawa Prawo Łowieckie, iż celem łowiectwa $w$ tym prowadzenie działań polegajacych na pozyskiwaniu zwierząt kopytnych $w$ ramach gospodarki łowieckiej, jest ochrona środowiska tj. zwierząt łownych (zwierzyny) i gospodarowanie ich zasobami w zgodzie z zasadami ekologii oraz zasadami racjonalnej gospodarki rolnej, leśnej i rybackiej, wyklucza uznanie tej działalności za mogaca znaczaco negatywnie oddziaływać na cele ochrony obszaru Natura 2000 lub obszar znajdujaccy się na liście, o której mowa w art. 27 ust. 3 pkt 1. Godzi to bowiem w podstawowe cele jakim ma służyć łowiectwo, wyrok WSA Warszawa, sygn. akt IV SA/Wa 217/14. 


\section{Podsumowanie}

- Teza, jakoby pobyt myśliwych, psów myśliwskich i pojazdów w siedliskach stanowił jako taki naruszenie art. 4 ust. 4 dyrektywy ptasiej jest zbyt daleko idąca. Oceny zgodności z dyrektywą należy bowiem dokonywać na poziomie lokalnym, z uwzględnieniem cech siedliska i charakteru polowania.

- Postulowane w analizowanej opinii ewentualne ograniczenia lub zakazy polowania na ptaki łowne określonych gatunków z uwagi na ich podobieństwo do gatunków objętych ochroną powinny być dokonywane w skali lokalnej, z uwzględnieniem takich czynników, jak rzeczywiste podobieństwo danych gatunków, prawdopodobieństwo wystąpienia pomyłki czy względnie znaczne występowanie podobnych gatunków w tym samym czasie i miejscu objętym polowaniem.

- Na poziomie ustawowym wymóg inwentaryzacji zwierzyny został zrealizowany, zaś wyłączenie spod niego ptaków migrujących wiąże się z brakiem praktycznej możliwości wiarygodnego oszacowania ich liczebności na potrzeby planowania gospodarki łowieckiej.

- Określenie różnych dat zakończenia okresu polowania dla różnych regionów danego państwa członkowskiego jest dopuszczalne, jednak pod warunkiem zapewnienia pełnej ochrony ptakom migrującym. Ocena zasadności tezy zawartej w analizowanej opinii, jakoby okresy ochronne dla wskazanych gatunków ptaków były zbyt krótkie, powinna zostać przeprowadzona dla danego obszaru, $\mathrm{z}$ uwzględnieniem elementów szczegółowo określonych w wytycznych Komisji Europejskiej z $2008 \mathrm{r}$.

- Należy zgodzić się z tezą, że stosowanie śrutu ołowianego na obszarach szczególnej ochrony może zostać uznane za niezgodne z wymogami ochrony tych terenów.

- Teza, zgodnie z którą bażanty i kuropatwy mogą zostać uznane za zwierzynę łowną dopiero po okresie wyprowadzenia własnych lęgów, jest zbyt daleko idąca i nadmiernie zawęża interpretację pojęcia „polowanie”, w konsekwencji bezpodstawnie poszerzając zakres stosowania rozporządzenia 1099/2009.

- Praktyka polegająca na generalnym wyłączeniu planów łowieckich spod wymogu poddania ocenie wpływu na dany teren, o której mowa w art. 6 ust. 3 dyrektywy siedliskowej, może zostać uznana za niezgodną z tym przepisem.

\section{Bibliografia}

Fäth J. i in., Leaching behavior and ecotoxicological effects of different game shot materials in freshwater, „Knowledge \& Management of Aquatic Ecosystems” 2018, No 419(24), https://doi.org/10.1051/kmae/2018009.

Kurcz B., Dyrektywy Wspólnoty Europejskiej i ich implementacja do prawa krajowego, Kraków 2004. 
Radecki W., Prawo łowieckie - komentarz, Warszawa 2014.

Rakoczy B., Stec R., Woźniak A., Prawo łowieckie. Komentarz, 2014, LEX.

Ribaut J.P., How the Bern Convention Came into Being, „Naturopa” 2004, nr 101.

Verschuuren J.M., Implementation of the Convention on Biodiversity in Europe: 10 Years of Experience with the Habitats Directive, „Journal of International Wildlife Law and Policy" 2002, No 5.

Wylegała P., Ławicki Ł., Głowienka, czernica, cyraneczka, łyska - stan populacji w Polsce i wpływ gospodarki łowieckiej. Opinia na potrzeby Polskiego Komitetu Krajowego IUCN, PTOP Salamandra, Poznań 2019. 